\title{
Seasonal pattern of nutrient cycling in the Atlantic Forest across a topographic gradient
}

\author{
Padrão sazonal da ciclagem de nutrientes na Floresta Atlântica em um \\ gradiente topográfico
}

Jônio Pizzol Caliman ${ }^{1}$ (D), Tiago de Oliveira Godinho² (10, Marcos Vinicius Winckler Caldeira ${ }^{3}$ (D), José Henrique Tertulino Rocha ${ }^{4}$ (D), Miles Louis Drury ${ }^{5}$, Kallil Chaves Castro 3 (1)

${ }^{1}$ Universidade Federal de Viçosa - UFV, Viçosa, MG, Brasil

${ }^{2}$ Vale S.A., Reserva Natural Vale - RNV, Linhares, ES, Brasil

${ }^{3}$ Universidade Federal do Espírito Santo - UFES, Jerônimo Monteiro, ES, Brasil

${ }^{4}$ Faculdade de Ensino Superior e Formação Integral - FAEF, Garça, SP, Brasil

${ }^{5}$ University of Eastern Finland - UEF, Kuopio, North Savo, Finland

How to cite: Caliman, J. P., Godinho, T. O., Caldeira, M. V. W., Rocha, J. H. T., Drury, M. L., \& Castro, K. C. (2020). Seasonal pattern of nutrient cycling in the Atlantic Forest across a topographic gradient. Scientia Forestalis, 48(125), e3200. https://doi.org/10.18671/scifor.v48n125.23

\begin{abstract}
Litter layer is the layer of organic detritus accumulated on the soil in forest ecosystems and can be influenced by biologic, edaphic, and climatic factors, increasing from boreal forest to the tropics, and being highly related with the net primary production of forest. In the present study litter was analyzed in three topographic positions; the effect of weather on the litterfall and litter layer amount, the amount of nutrients deposited, accumulated, and released from the litter layer to the soil and C stocks in the forest floor. No differences were found in the amount of litterfall deposited in the plots from the top, middle, and bottom of the hill. There was a large variation in the litterfall throughout the year. The highest litterfall rate was found at the end of the dry season. During the months of very low rainfall, greater litterfall and litter layer were found in the top hill plots. Litterfall is an important mechanism of the transference of nutrients from plants to soil, especially in the non-mobile nutrients and N, due to the high $\mathrm{N}$ concentration in the leaves and to the high dominance of Fabaceae trees. In 17 months, around $6.7 \mathrm{Mg} \mathrm{ha}^{-1}$ of $\mathrm{C}$ was deposited on the soil and a mean $2.6 \mathrm{Mg} \mathrm{ha}^{-1}$ were stored in the litter layer. In the year 2010, in the 12 months, the annual decomposition rate was 1.68.
\end{abstract}

Keywords: Carbon stock; Climatic elements; Litterfall; Litter layer; Nutrients; Soil fertility.

\section{RESUMO}

A serapilheira é a camada de detritos orgânicos acumulados sobre o solo em ecossistemas florestais e pode ser influenciada por fatores biológicos, edáficos e climáticos, aumentando da floresta boreal para os trópicos, é altamente relacionada com a produção primária líquida de floresta. No presente estudo foi analisada a serapilheira em três posições topográficas, o efeito do clima na quantidade de serapilheira depositada e acumulada sobre o solo, a quantidade de nutrientes depositados, acumulados e liberados para o solo e os estoques de $\mathrm{C}$ no solo da floresta. Não foram encontradas diferenças na quantidade de serapilheira depositada nas parcelas de topo de morro, encosta e baixada. Observou-se grande variação na produção de serapilheira ao longo do ano. A maior deposição de serapilheira foi encontrada no final da estação seca. Durante os meses com precipitação muito baixa, maior produção e acúmulo de serapilheira foram encontradas nas parcelas de topo de morro. A produção de serapilheira é um importante mecanismo de transferência de nutrientes das plantas para o solo, principalmente os nutrientes não móveis e o $\mathrm{N}$, devido ao elevado teor de $\mathrm{N}$ nas folhas e à alta dominância de árvores da família Fabaceae. Em 17 meses, cerca de 6,7 $\mathrm{Mg} \mathrm{ha}^{-1}$ de $\mathrm{C}$ foram

Financial support: Fundação de Amparo à Pesquisa e Inovação do Espírito Santo - FAPES (Process Number: 54695490/2011 and 59835478/2012). Conflict of interest: Nothing to declare.

Corresponding author: godinhoto@hotmail.com

Received: 8 December 2018

Accepted: 13 June 2019.

Editor: Francides Gomes da Silva Júnior.

(c) (i) This is an Open Access article distributed under the terms of the Creative Commons Attribution License, which permits unrestricted use,

cc) distribution, and reproduction in any medium, provided the original work is properly cited. 
depositados no solo e uma média de 2,6 $\mathrm{Mg} \mathrm{ha}^{-1}$ foram armazenados na camada de serapilheira. No ano de 2010, ou seja, em 12 meses, a taxa de decomposição anual foi de 1,68.

Palavras-chave: Estoque de carbono; Elementos climáticos; Produção de serapilheira; Camada de serapilheira; Nutrientes; Fertilidade do solo.

\section{INTRODUCTION}

Litter layer is the layer of organic detritus accumulated on the soil in forest ecosystems, being composed of leaves, branches, bark, fruits, flowers, seeds, and other plants and animals' detritus (Olson, 1963). The litter layer plays an important role in forest ecosystems: it is part of the nutrient cycling process (soil-plant-atmosphere); it protects the soil against erosion, leaching, and compaction and it is the main energy source for the soil microbial community in addition to regulating the soil temperature and humidity (Attwill, 1995; Vitousek \& Sanford Junior, 1986).

The annual litterfall can be influenced by biologic, edaphic, and climatic factors, increasing from boreal forest to the tropics, and being highly related with the net primary production of the forest (Bray \& Gorham, 1964; Godinho et al., 2013a; Vogel et al., 2007). The litterfall rate also shows high variation thought the year, also being related to weather conditions (Godinho et al., 2013a; Vital et al., 2004); for example, high or low precipitation, high or low temperature, and wind speed.

The amount of litter layer is directly related to the difference between the litterfall and the decomposition rate; this process being the main way nutrients return to soil to be taken up by trees (Vitousek \& Sanford Junior, 1986). Caldeira et al. (2008) also point to other factors which might affect the litter layer, such as: species composition, forest type, canopy continuity, edaphoclimatic conditions, forest management, decomposition rate, fire, insect attacks, and forest harvest intensity.

Litter layer decomposition is a vital process for the forest ecosystem in which essential nutrients are mineralized. Also, in this process the larger part of $\mathrm{C}$ is released to the atmosphere as $\mathrm{CO}_{2}$ and part is stabilized as soil organic matter (Stevenson \& Cole, 1999). A series of studies have been carried out to clarify the relationships between the litter decomposition with weather conditions, soil properties, microbial community, and litter quality (Bachega et al., 2016; Peh et al., 2012; Rocha et al., 2015). The knowledge of this process will be helpful to match species to site conditions when the objective is improving the soil quality and/or soil C sequestration (Caldeira et al., 2008).

This study examined the effects of topographic gradient and weather (different conditions of mean air temperature, air humidity, wind speed, radiation, and precipitation) on the litterfall and litter layer during 17 months in an Atlantic Forest. The aim of this study was to determine: i) the litterfall rate in three topographic position (top, middle, and bottom of the hill); ii) the amount of nutrients deposited, accumulated, and released from the litter layer to the soil; iii) C stocks in the forest floor; and, iv) the effect of the average air temperature, air humidity, wind speed, radiation, and precipitation (different weather conditions) on litterfall and litter layer amount.

\section{MATERIAL AND METHODS}

\section{Study site}

This study was carried out in the RPPN (Reserva Particular do Patrimônio Natural) Cafundó in the state of Espírito Santo, Brazil $\left(20^{\circ} 43^{\prime} \mathrm{S}\right.$ and $\left.41^{\circ} 13^{\prime} \mathrm{W}\right)$. The RPPN Cafundó is a private 517 ha natural forest reserve being part of Atlantic Forest biome (Floresta Estacional Semidecidual Submontana by the Brazilian classification) (Instituto Brasileiro de Geografia e Estatística, 2012). The topography of the region is hilly, with declivity changing from 1 to $25 \%$ at between 91 to $160 \mathrm{~m}$ above sea level. The Köppen climatic classification for this site is Aw, with an annual medium air temperature of $22.2{ }^{\circ} \mathrm{C}$ and annual medium precipitation of 
$1162 \mathrm{~mm}, 73 \%$ occurring between October to March (Alvares et al., 2013). The soil of the region is a very deep Typical Ferralsol (Food and Agriculture Organization of the United Nations, 2015) (Table 1).

Table 1. Soil attributes of the $0-20 \mathrm{~cm}$ layer and traits of the studied forest (Bottom $n=8$, Middle $n=2$ and Top $n=2$ ).

\begin{tabular}{|c|c|c|c|}
\hline Parameter ${ }^{(1)}$ & Bottom & Middle & Top \\
\hline Density (stem ha-1) ${ }^{(2)}$ & $1785 \pm 241^{(3)}$ & $1625 \pm 106$ & $1550 \pm 212$ \\
\hline Dominance $\left(\mathrm{m}^{2} \mathrm{ha}^{-1}\right)^{(2)}$ & $38.93 \pm 10.84$ & $24.76 \pm 2.14$ & $24.74 \pm 1.68$ \\
\hline Species (Und.) & $54 \pm 13$ & $42 \pm 7$ & $29 \pm 2$ \\
\hline Declivity (\%) & $3.81 \pm 3.23$ & $20 \pm 7.07$ & $5.00 \pm 5.66$ \\
\hline Altitude (m a.s.l.) & $100 \pm 7$ & $119 \pm 35$ & $143 \pm 25$ \\
\hline $\mathrm{pH}\left(\mathrm{H}_{2} \mathrm{O}\right)$ & $6.24 \pm 0.20$ & $5.80 \pm 0.52$ & $5.09 \pm 0.56$ \\
\hline$P\left(\mathrm{mg} \mathrm{dm}^{-3}\right)$ & $8.99 \pm 7.86$ & $1.68 \pm 0.35$ & $2.13 \pm 0.07$ \\
\hline $\mathrm{K}\left(\mathrm{mg} \mathrm{dm} \mathrm{m}^{-3}\right)$ & $63.67 \pm 31.80$ & $60.12 \pm 1.71$ & $54.63 \pm 24.81$ \\
\hline $\mathrm{Ca}^{2+}\left(\mathrm{cmol}_{\mathrm{c}} \mathrm{dm}^{-3}\right)$ & $4.72 \pm 2.12$ & $3.66 \pm 0.77$ & $2.12 \pm 0.83$ \\
\hline $\mathrm{Mg}^{2+}\left(\mathrm{cmol}_{\mathrm{c}} \mathrm{dm}^{-3}\right)$ & $1.22 \pm 0.66$ & $1.16 \pm 0.46$ & $0.82 \pm 0.33$ \\
\hline $\mathrm{Al}^{3+}\left(\mathrm{cmol}_{\mathrm{c}} \mathrm{dm}^{-3}\right)$ & $0.00 \pm 0.00$ & $0.02 \pm 0.02$ & $0.35 \pm 0.39$ \\
\hline Organic C (\%) & $1.65 \pm 0.30$ & $1.57 \pm 0.21$ & $1.97 \pm 0.24$ \\
\hline
\end{tabular}

(1)Data adapted from Archanjo et al. (2012) and Godinho et al. (2013b); (2)Density and dominance were calculated with base in all tree species with diameter at breast high $(\mathrm{DBH})>5 \mathrm{~cm} ;{ }^{(3)}$ Standard deviation.

The RPPN Cafundó forest has never been clear felled but had been under selective harvest of high value timbers for a long time, but has been unmanaged since 1940, being in a secondary stage of regeneration. The forest has 255 tree species of 152 genera and 54 families with a Shannon's diversity index $\left(\mathrm{H}^{\prime}\right)$ of 4.13 , equitability $(\mathrm{J})$ of 0.74 , basal area of

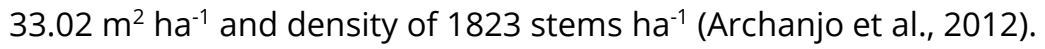

\section{Litterfall and litter layer assessment}

The sampling were carried out in 12 plots of $1000 \mathrm{~m}^{2}(20 \times 50 \mathrm{~m})$ placed systematically in the forest. These plots were the same as those used by Archanjo et al. (2012) for a floristic survey. In this study, eight plots were used in bottom areas, two plots in middle areas, and two plots in top areas. The number of plots ( $n$ ) at each topographic position was different due to the sampling method used by Archanjo et al. (2012). The above-mentioned author used the method of sampling fixed-area plots, systematically distributed in the field (with a distance of 350 meters between each plot).

Five litter collectors of $0.25 \mathrm{~m}^{2}(0.5 \times 0.5 \mathrm{~m}$ - at a height of $0.75 \mathrm{~m}$ from the forest ground) were installed in each plot. These five litter collectors were placed one at each corner of the plot and one at the center of the plot. The litterfall deposited in the collectors was collected on a monthly basis. After collection, in the laboratory, the litterfall was classified as leaves (including flowers and fruits) or branches (including bark pieces). After classification, the litterfall samples were oven-dried to constant mass $\left(65^{\circ} \mathrm{C}\right)$ and weighted.

The litter layer was also sampled on a monthly basis, being collected in a randomised way 12 individual samples per plot. The samples were collected with a steel frame of $0.0625 \mathrm{~m}^{2}(0.25 \times 0.25 \mathrm{~m})$. After sampling the litter layer samples were oven-dried to constant mass $\left(65^{\circ} \mathrm{C}\right)$ and weighted. The sampling were made from December 2009 to April 2011, totalling 17 months, and including all weather seasons.

The concentration of $\mathrm{N}, \mathrm{P}, \mathrm{K}, \mathrm{Ca}, \mathrm{Mg}, \mathrm{S}, \mathrm{Fe}, \mathrm{Cu}, \mathrm{B}, \mathrm{Mn}$, and $\mathrm{Zn}$ were determined after wet digestion, and $\mathrm{C}$ after dry combustion. After sulphuric digestion, $\mathrm{N}$ was determined by the micro Kjeldahl method. After nitro-perchloric digestion the $\mathrm{P}, \mathrm{S}$, and $\mathrm{B}$ were determined by colorimetry, and the $\mathrm{K}, \mathrm{Ca}, \mathrm{Mg}, \mathrm{Fe}, \mathrm{Cu}, \mathrm{Mn}$, and $\mathrm{Zn}$ by atomic absorption spectrometry (Silva, 2009; Tedesco, 1995). The amount of each nutrient deposited by litterfall and accumulated in the litter layer was calculated for each month. 


\section{Litter decomposition rate (k)}

The decomposition rate of the litter was calculated using the method proposed by Olson (1963) (Equation 1). The time necessary for decomposition of 50 and $95 \%\left(T_{50 \%}\right.$ and $\left.T_{95 \%}\right)$ of the litter layer was also calculated by the Equations 2 and 3.

$$
\mathrm{k}_{\mathrm{i}}=\frac{\mathrm{L}_{\mathrm{i}}}{\mathrm{Xss}_{\mathrm{i}}}
$$

Where:

$\mathrm{ki}=$ is the decomposition constant of component $\mathrm{i}$;

$\mathrm{Li}=$ is the deposition of the component $\mathrm{i}$;

Xssi $=$ is the amount of component $i$ accumulated on the soil.

$$
\mathrm{T}_{50 \%}=0.693 / \mathrm{k}
$$

$$
\mathrm{T}_{95 \%}=3 / \mathrm{k}
$$

\section{Data analysis}

To assess the effect of the position in the hill (top, middle, and bottom) on the assessed attributes, the variances were analysed using the one-way F test followed by the Tukey's HSD test at $5 \%$ of probability. To test the effect of monthly variation in the litterfall and litter layer, the variances were analysed using the one-way $\mathrm{F}$ test followed by Tukey's HSD test at 5\% of probability. The relationship between the climatic data, the litterfall rate, and litter layer accumulation were determined using the principal components analysis (PCA). The weather information was collected in a weather station $30 \mathrm{~km}$ from the RPPN Cafundó (period from December 2009 to April 2011, totalling 17 months). The mean air temperature, air humidity, wind speed, radiation, and precipitation were used in this analysis. The Kaiser-Guttman criteria $(\lambda>1.0$; Cliff, 1988; Guttman, 1954; Jackson, 1993) was used to select the axis to be considered in the PCA analysis. All the analyses were calculated in the software R v3.1.0 (R Core Team, 2017).

\section{RESULTS AND DISCUSSION}

\section{Litterfall and litter layer amounts}

After 17 months of sampling, no differences were found in the amount of litterfall deposited in the plots from the top, middle, and bottom of the hill $(p>0.05)$. The leaves deposition was around eight times greater than the branches deposition. The amount of litter layer accumulated on the soil also was not influenced by the position of the plot in the hill, presenting an average of $5.23 \mathrm{Mg} \mathrm{ha}^{-1}(\mathrm{p}>0.05)$ (Table 2).

Table 2. Litterfall (total of 17 assessed months) and litter layer of an Atlantic Forest in plots located at the top, middle and bottom of the hill (Bottom $n=8$, Middle $n=2$ and Top $n=2$ ).

\begin{tabular}{cccc}
\hline \multirow{2}{*}{ Component } & Bottom & Middle & Top \\
\cline { 2 - 4 } & & Mg ha $^{-1}$ & \\
\cline { 2 - 4 } & $10.67 \pm 0.38^{(1)}$ & $11.10 \pm 0.43$ & $11.29 \pm 0.39$ \\
Leaves & $1.46 \pm 0.06$ & $1.35 \pm 0.05$ & $1.54 \pm 0.07$ \\
Branches & $12.13 \pm 0.42$ & $12.45 \pm 0.46$ & $12.83 \pm 0.44$ \\
Total & $4.91 \pm 1.15$ & $5.26 \pm 1.19$ & $5.53 \pm 1.25$ \\
Litter layer & &
\end{tabular}

(1)Standard deviation. 
Large variation in the litterfall was found throughout the year (Leaves: $p<0.001$; Branches: $p<0.001$; Total: $p<0.001$ ). The largest amounts of litterfall were observed from September to December and the lowest from May to August. Small variation between the months was also found to amount of litter layer $(p<0.001)$ (Figure 1).

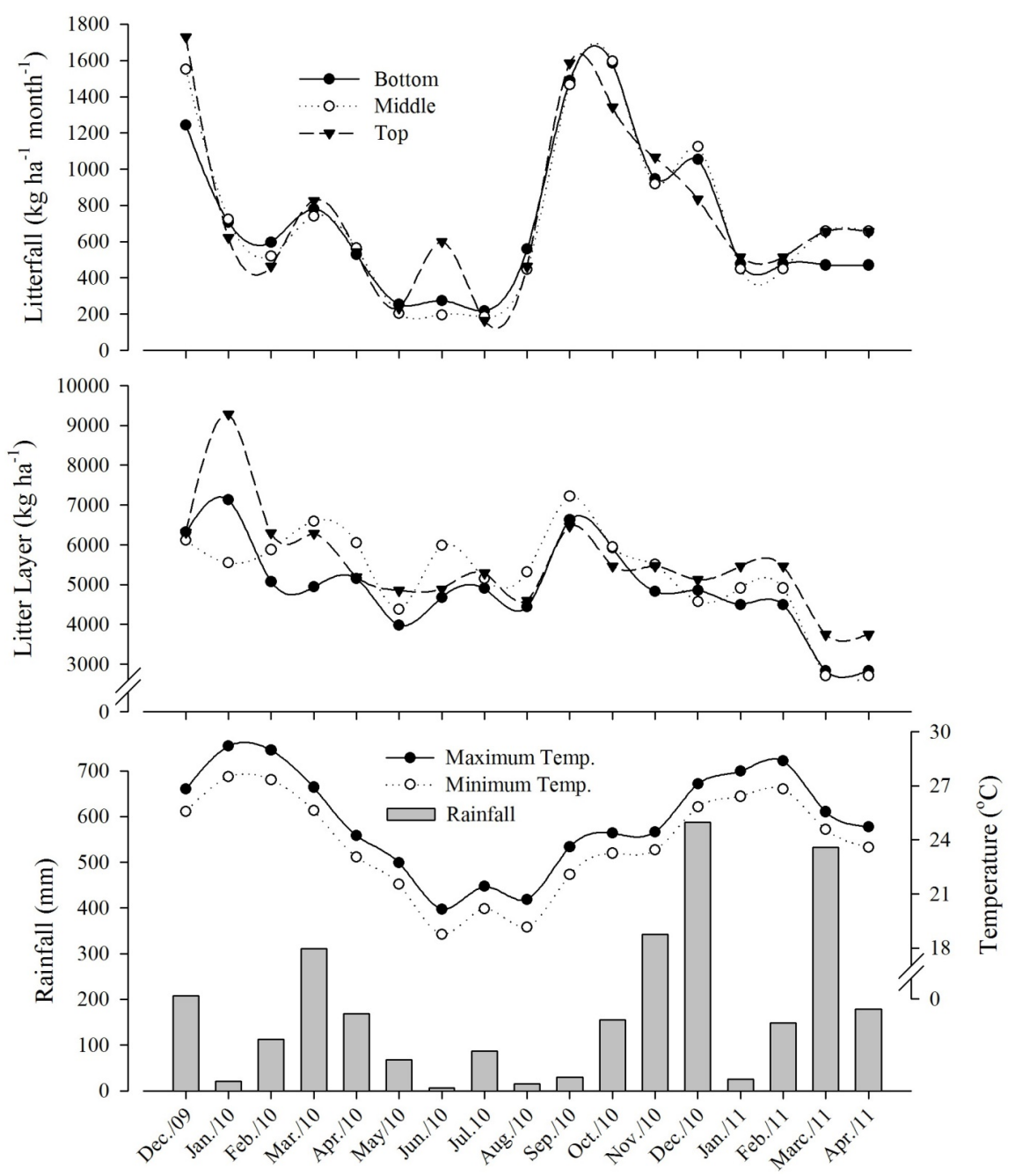

Figure 1. Atlantic Forest litterfall and litter layer at the top, middle and bottom of the hill, rainfall and air temperature from December of 2009 to April of 2011 (Bottom n=8, Middle $n=2$ and Top $n=2$ ).

No difference was found between the plots position $(p>0.05)$.

The leaf percentage in the total litterfall was around $88 \%$, being higher than the proportion found in other studies, which typically ranged from 60 to 80\% (Bray \& Gorham, 1964; Calvi et al., 2009; Cunha et al., 1993; Schumacher et al., 2011). The larger contribution of this fraction in our study can be associated with the presence of other materials, such as flowers and fruits. However, as in this study, the leaves had been found as the main fraction of the litterfall in many other studies (Antoneli \& Francisquini, 2015; Aryal et al., 2015; Godinho et al., 2013a; Paudel et al., 2015; Scoriza \& Piña-Rodrigues, 2014; Turchetto \& Fortes, 2014).

The low effect of topographic position on litterfall and litter layer can be associated with the elevated regeneration stage of this forest. Despite some differences in the floristic component, in all topographic positions ' high diversity and density of species was found (Archanjo et al., 2012). Ferreira et al. (2015) also found no difference between the topographic positions on the litter in a region with hilly topography. However, strong differences were found in sites with steeper topography, in general with high litterfall and litter layer in the top 
position (Borém \& Ramos, 2002; Moreira \& Silva, 2004). Despite of the non-significance, high litter layer and litterfall were found on the top hill plots in January and July 2010, respectively. The high litter production on the top hill plots during dry month can be associated to the lowest observed precipitations, higher drainage in the soil of such position (Gonçalves et al., 2017), and with plants strategy for reduction of water and energy loss.

Using different amounts of experimental plots at each topographic position may mask the results, but many researchers conduct their research in this way. In a series of studies conducted in a region of the Atlantic Rainforest, Alves et al. $(2010,2012)$ and Souza-Neto et al. (2017) used different numbers of sample plots at each topographic position to analyse litter production.

In a review by Martinelli et al. (2017), the authors summarized the data from 105 estimates of fine litterfall production from 45 sites in the Atlantic Forest domain, including two types of forests, evergreen and seasonal, and two successional stages, secondary and old growth. The overall litterfall average was $8.0 \pm 2.5 \mathrm{Mg} \mathrm{ha}^{-1}$. They emphasized that litterfall was significantly higher in seasonal forests than in evergreen forests and in old growth than in secondary forests. Leaves were the major components of the litterfall, contributing with 68 per cent of the total. The second most important component was branches, contributing 22 percent, followed by reproductive organs (flowers and fruits), at 6 percent.

The combination of high litterfall and the rapid recovery of secondary forests raises the possibility of using these forests to sequester carbon to help mitigate the effects of global warming (Bonner et al., 2013; Gilroy et al., 2014). This aspect is especially important in the Atlantic Forest, where most of the old growth forest has been logged over and the area is experiencing the first signs of forest transition (Ferreira et al., 2015; Lira et al., 2012).

In most sites studied by Martinelli et al. (2017), litterfall was highest at the end of winter and beginning of spring (August to November in the Southern Hemisphere), with a peak observed in September, corresponding to the end of the dry season in the South-Southeast region of Brazil.

The high litterfall found at the end of the dry season (Sep. and Oct.) is common for this kind of forest. In this forest from 20 to $50 \%$ of the constituent tree species are deciduous (losing their leaves in the dry season), leading to its classification as semi-deciduous (Instituto Brasileiro de Geografia e Estatística, 2012). A similar pattern for this kind of forest is also found by other authors (Arato et al., 2003; Martins \& Rodrigues, 1999; Pinto et al., 2008; Vital et al., 2004). The loss of leaves at the end of the dry season in forests within a region of well-defined dry and rain seasons has been seen as a strategy to avoid water stress (Delitti, 1995). However, this pattern has been found only in forests close or in climax state and not in forests in the initial stages of regeneration (Pires et al., 2006).

The amount of litter layer found in this study $\left(5.5 \mathrm{Mg} \mathrm{ha}^{-1}\right)$ was smaller than the amount found by other authors (Diniz \& Pagano, 1997; Santos \& Válio, 2002; Schumacher et al., 2011). However, a large variation in the amount of litter layer has been reported, with values ranging from 5.8 to $25.0 \mathrm{Mg} \mathrm{ha}{ }^{-1}$. The main factor that can influence the litter layer accumulation are species composition, regeneration stage, growth rate (NPP), and weather conditions (Vital et al., 2004; Pimenta et al., 2011; Pinto et al., 2008; Schumacher et al., 2011).

\section{Nutrients stocks in the litterfall and litter layer}

Between the macronutrients, the highest deposition rate during the 17 studied months was found to be Ca in the middle and bottom plots ( $287.40 \mathrm{~kg} \mathrm{ha}^{-1}$ and $\left.298.02 \mathrm{~kg} \mathrm{ha}^{-1}\right)$ and $\mathrm{N}$ in the top plots $\left(265.28 \mathrm{~kg} \mathrm{ha}^{-1}\right)$. The amount of nutrients deposited in the middle and bottom plots were $\mathrm{Ca}>\mathrm{N}>\mathrm{K}>\mathrm{Mg}>\mathrm{S}>\mathrm{P}$, and in the top plot was $\mathrm{N}>\mathrm{Ca}>\mathrm{K}>\mathrm{Mg}>\mathrm{S}>\mathrm{P}$ (Table 3). 
Table 3. Amount of nutrients deposited by litterfall (total of 17 assessed months) and accumulated in the litter layer of an Atlantic Forest in plots located in the top, middle and bottom of the hill (Bottom $\mathrm{n}=8$, Middle $\mathrm{n}=2$ and Top $\mathrm{n}=2$ ).

\begin{tabular}{|c|c|c|c|c|c|c|}
\hline & \multicolumn{3}{|c|}{ Litterfall (kg ha-1) } & \multicolumn{3}{|c|}{ Litter Layer (kg ha-1) } \\
\hline & Bottom & Middle & Top hill & Bottom & Middle & Top hill \\
\hline $\mathrm{N}$ & 244.40 & 250.33 & 265.28 & 92.58 & 95.90 & 102.60 \\
\hline $\mathrm{P}$ & 14.53 & 9.70 & 10.98 & $4.17^{\mathrm{a}}$ & $3.40^{\mathrm{b}}$ & $3.10^{b}$ \\
\hline $\mathrm{K}$ & 87.20 & 77.07 & 69.09 & 13.61 & 11.67 & 10.19 \\
\hline $\mathrm{Ca}$ & 287.40 & 298.02 & 225.66 & 152.16 & 145.99 & 121.17 \\
\hline Mg & 35.50 & 33.59 & 31.47 & 10.96 & 10.06 & 10.08 \\
\hline $\mathrm{S}$ & 30.75 & 30.46 & 29.70 & 8.35 & 8.41 & 8.44 \\
\hline $\mathrm{Fe}$ & 2.8433 & 3.0704 & 4.3351 & $4.5361^{b}$ & $8.5673^{b}$ & $13.7704^{\mathrm{a}}$ \\
\hline $\mathrm{Cu}$ & 0.0842 & 0.0942 & 0.0879 & $0.0376^{b}$ & $0.0467^{a b}$ & $0.0483^{a}$ \\
\hline $\mathrm{Mn}$ & $2.1845^{b}$ & $2.4237^{b}$ & $5.2969^{a}$ & $1.2068^{b}$ & $1.5047^{\mathrm{b}}$ & $2.5687^{a}$ \\
\hline $\mathrm{Zn}$ & 0.3158 & 0.3524 & 0.3618 & $0.1496^{b}$ & $0.1680^{\mathrm{ab}}$ & $0.1865^{a}$ \\
\hline B & 0.6186 & 0.7708 & 0.7450 & 0.1845 & 0.2157 & 0.2055 \\
\hline C & 6483.72 & 6595.57 & 6968.70 & 2482.50 & 2556.12 & 2814.39 \\
\hline
\end{tabular}

Number followed by the same letter or not followed by letter for each nutrient are not significantly different by the Tukey's test at $5 \%$ of probability.

For micronutrients, the highest deposition was found to be Fe in the middle and bottom plots (2.83 kg ha-1 and $\left.3.07 \mathrm{~kg} \mathrm{ha}^{-1}\right)$ and $\mathrm{Mn}$ in the top plots $\left(5.29 \mathrm{~kg} \mathrm{ha}^{-1}\right)$. The amount of micronutrients deposited in the middle and bottom plots was $\mathrm{Fe}>\mathrm{Mn}>\mathrm{B}>\mathrm{Zn}>\mathrm{Cu}$, and in the top plot was $\mathrm{Mn}>\mathrm{Fe}>\mathrm{B}>\mathrm{Zn}>\mathrm{Cu}$. The amount of $\mathrm{C}$ deposited during the 17 months change from 6484 to $6969 \mathrm{~kg} \mathrm{ha}^{-1}$ in the bottom and top respectively, but was not significant (Table 3).

The amount of macro and micronutrients accumulated in the litter layer was the same observed in litterfall the middle and bottom plots, being $\mathrm{Ca}>\mathrm{N}>\mathrm{K}>\mathrm{Mg}>\mathrm{S}>\mathrm{P}$ and $\mathrm{Fe}>\mathrm{Mn}$ $>\mathrm{B}>\mathrm{Zn}>\mathrm{Cu}$ and did not change by plot position. The amount of $\mathrm{C}$ accumulated in the litter layer changed from 2483 to $2814 \mathrm{~kg} \mathrm{ha}^{-1}$ in the bottom and top plots respectively and was not significant (Table 3).

The amount of macro and micronutrients deposited throughout litterfall was around $685 \mathrm{~kg} \mathrm{ha}^{-1}$ and the amount of $\mathrm{C}$ deposited was around $6.7 \mathrm{Mg} \mathrm{ha}^{-1}$. The amount of macro and micronutrients accumulated in the forest floor was around $280 \mathrm{~kg} \mathrm{ha}^{-1}$ and the amount of $\mathrm{C}$ accumulated was around $2.6 \mathrm{Mg} \mathrm{ha}^{-1}$.

The nutrients deposition rate by litterfall is influenced by the season, edapho-climatic conditions, species, nutrient studied, compartment considered in the study, phenology, succession stage, and assessment method (Den Besten et al., 2014; Silva et al., 2013; Wood et al., 2006; Zelarayán et al., 2015). In general, $\mathrm{N}$ and Ca were the most deposited macronutrients and $\mathrm{Fe}$ and $\mathrm{Mn}$ the most deposited micronutrients. This was also found in many other studies in tropical forests (Caldeira et al., 2008; Cuevas \& Medina, 1986; Cunha et al., 2009; Diniz et al., 2015; Godinho et al., 2013a; Vitousek \& Sanford Junior, 1986).

The amount of Ca deposited by litterfall is associated with its low or non-mobility in the plants (Caldeira et al., 2008; Marschner, 1995). Due to this fact Ca is mainly cycled by a biogeochemistry route, such as deposition of senescent tissues (Nilsson et al., 1995). Despite the high mobility of $\mathrm{N}$ in the plants, the $\mathrm{N}$ deposition and accumulation in the litter layer can be accredited to dominance of trees in the Fabaceae family, which are $\mathrm{N}_{2}$ fixing species (Cunha Neto et al., 2013; Diniz et al., 2015). Species of the Fabaceae family represented 17\% 
of the individual numbers and 31\% of the basal area in the plots (Archanjo et al., 2012). In addition, litter production is the main way of transferring $\mathrm{N}$ from plants to soil because leaves constitute about $88 \%$ or more of the litter and their tissues have high $\mathrm{N}$ concentrations.

Deposition and accumulation in the litter layer of $\mathrm{P}, \mathrm{K}$, and $\mathrm{Mg}$ can be related to the high mobility of these nutrients, with internal translocation (biochemistry) being the main route of cycling. Furthermore, $\mathrm{K}$ does not form any organic compost in the plants, being found in a free form in the cellular content, being easily leachable from the canopy to soil (Caldeira et al., 2008; Marschner, 1995; Vital et al., 2004).

The Fe deposition by litterfall can be associated with the low mobility of this nutrient in the growing plants (Dechen \&Nachtigall, 2006; Malavolta, 2006). This low mobility also can be affected by several external factors, such as high $\mathrm{P}$ and/or $\mathrm{Mn}$ availability, $\mathrm{K}$ deficiency, and low solar radiation. The soil clay content, soil $\mathrm{pH}$, and soil organic matter also can influence Fe cycling because they influence Fe availability (Dechen \& Nachtigall, 2006).

The $\mathrm{Mn}$ deposition and accumulation in the litter layer can be associated with the high availability of this nutrient in acidic soils (in the case of this study) and the low mobility of this nutrient in the leaves (Heenan \& Campbell, 1983). However, in addition to Fe, the Mn content in the litter layer can be associated with the contamination by Fe and Mn soil oxy-hydroxides (Dechen \& Nachtigall, 2006).

Mn was the only element affected by topographic position. Its higher deposition at the top of the hill plots can be associated with the higher availability of this nutrient in such position. The high Mn availability in the hill top sites is associated with better drainage and consequential availability of $\mathrm{O}_{2}$ which results in higher oxidation and consequent availability of this nutrient (Brady \& Weil, 2013). The B in the litterfall also can be associated with the low mobility of this nutrient, resulting in higher cycling through the biogeochemistry route (Marschner, 1995).

\section{Annual decomposition rate (k)}

The $\mathrm{k}$ of the litter in the bottom, middle and top of the hill was 1.73, 1.53 and 1.52 respectively. Among macronutrients, the highest decomposition rate (consequently highest release speed) was observed for $\mathrm{K}$ and the lowest was found for Ca. Among micronutrients, the highest release speed was found for B and the lowest for Fe. The $k$ of $C$ was 1.81, 1.67 and 1.57 in the plots located at the bottom, middle and top of the hill respectively. The number of days needed to release $50 \%\left(T_{50 \%}\right)$ of the initial mass of the $\mathrm{C}$ was around 151 days and the time needed to release $95 \%$ of C ( $\left.\mathrm{T}_{95 \%}\right)$ was around 653 days (Table 4).

Table 4. Decomposition rate $(k)$ in 2010 (12 months), time needed for decomposition of 50\% ( $T_{50 \%}$ ) and $95 \%\left(T_{95 \%}\right)$ of the initial mass of litter, nutrients and $C$ of an Atlantic Forest in plots located at the top, middle and bottom of the hill (Bottom $n=8$, Middle $n=2$ and Top $n=2$ ).

\begin{tabular}{|c|c|c|c|c|c|c|c|c|c|}
\hline \multirow{2}{*}{ Nutrients } & \multicolumn{3}{|c|}{ k } & \multicolumn{3}{|c|}{$\mathbf{T}_{50 \%}$ (days) } & \multicolumn{3}{|c|}{$\mathbf{T}_{95 \%}$ (days) } \\
\hline & Bottom & Middle & Top hill & Bottom & Middle & Top hill & Bottom & Middle & Top hill \\
\hline $\mathrm{N}$ & 1.89 & 1.74 & 1.70 & 134 & 145 & 149 & 581 & 629 & 644 \\
\hline$P$ & 2.24 & 1.85 & 1.93 & 113 & 136 & 131 & 488 & 591 & 566 \\
\hline K & 4.85 & 4.84 & 5.04 & 52 & 52 & 50 & 226 & 226 & 217 \\
\hline $\mathrm{Ca}$ & 1.33 & 1.34 & 1.22 & 191 & 189 & 207 & 825 & 816 & 897 \\
\hline $\mathrm{Mg}$ & 2.34 & 2.21 & 2.09 & 108 & 114 & 121 & 468 & 494 & 524 \\
\hline$S$ & 2.78 & 2.68 & 2.55 & 91 & 94 & 99 & 393 & 409 & 429 \\
\hline $\mathrm{Fe}$ & 0.49 & 0.24 & 0.21 & 514 & 1076 & 1212 & 2225 & 4658 & 5248 \\
\hline $\mathrm{Cu}$ & 1.52 & 1.30 & 1.33 & 167 & 194 & 190 & 722 & 839 & 822 \\
\hline
\end{tabular}


Table 4. Continued...

\begin{tabular}{|c|c|c|c|c|c|c|c|c|c|}
\hline \multirow{2}{*}{ Nutrients } & \multicolumn{3}{|c|}{ k } & \multicolumn{3}{|c|}{$\mathbf{T}_{50 \%}$ (days) } & \multicolumn{3}{|c|}{$\mathbf{T}_{95 \%}$ (days) } \\
\hline & Bottom & Middle & Top hill & Bottom & Middle & Top hill & Bottom & Middle & Top hill \\
\hline $\mathrm{Mn}$ & 1.30 & 1.02 & 1.36 & 195 & 247 & 186 & 843 & 1069 & 806 \\
\hline $\mathrm{Zn}$ & 1.42 & 1.36 & 1.25 & 178 & 186 & 203 & 772 & 805 & 879 \\
\hline B & 2.42 & 2.38 & 2.46 & 104 & 106 & 103 & 452 & 460 & 445 \\
\hline$C$ & 1.81 & 1.67 & 1.57 & 140 & 152 & 161 & 605 & 657 & 696 \\
\hline Litter & 1.73 & 1.53 & 1.52 & 147 & 165 & 167 & 636 & 716 & 722 \\
\hline
\end{tabular}

Generally, temperate forests have a soil C pool greater than tropical forests (Olson, 1963). When we compare the $C$ deposition rate $\left(4717 \mathrm{~kg} \mathrm{ha}^{-1} \mathrm{y}^{-1}\right)$ and the amount accumulated (2617 kg ha-1) found in this study with the found in temperate forest (Jenny et al., 1949) the reason for this difference is clear. This is due to climatic conditions causing an increase in microbial activity, and consequently in decomposition rate, C mineralisation, and release to the atmosphere (Olson, 1963). The soil C pool is a response of the difference in $C$ inputs (mainly from litterfall and fine root turnover) with $C$ outputs (mainly by decomposition) (Baldock \& Skjemstad, 2000). The climatic factors (mainly temperature and humidity) play an important role in the microbial activity and consequently in the enzymatic activity and C mineralization (Pandey et al., 2007).

Despite finding no significant difference in the amount of litterfall and litter layer between position of the plots, a trend of increased $\mathrm{k}$ from the top to bottom was found. This fact might be due to increase in soil moisture content. Sites at the bottom of the hill receive water from side drainage for longer time than hill top sites after rain events. Annual decomposition rates ranging from 1.09 to 2.45 have been found for many authors in semi deciduous Atlantic Forests (Arato et al., 2003; Cunha et al., 1993; Turchetto \& Fortes, 2014; Vital et al., 2004; Pimenta et al., 2011). In evergreen tropical forests $k$ change of 0.68 to 2.34 has been found (Backes et al., 2005; Menezes et al., 2010; Pereira et al., 2013; Pires et al., 2006; Scheer, 2008).

Values of $\mathrm{k}$ higher than 1 indicate that decomposition is higher than litterfall, resulting in litter layer stocks smaller than the litterfall rate (Olson, 1963). This situation $(k>1)$ is found in forests of tropical climates, different from that observed in temperate and boreal forests, being influenced mainly by temperature and precipitation. With exception of $\mathrm{Fe}$, $\mathrm{k}$ was higher than 1 for all nutrients, $C$ and litter. This fact indicates semi deciduous forests as well as evergreen tropical forest have a high $\mathrm{C}$ and nutrient turnover. The high variation in the decomposition rate found in the literature can be associated with the soil moisture, temperature, microbial fauna, and quality of the deposited litter (related with species composition) (Anderson et al., 1983; Horwart, 2007; Turchetto \& Fortes, 2014).

Long term studies have shown that the forest $\mathrm{C}$ pool increases with the progression along the successional process (Chazdon et al., 2016; Pan et al., 2011), followed by a low reduction until reaching an equilibrium called steady state (Brienen et al., 2015; Pan et al., 2011; Phillivs et al., 2009; Poorter et al., 2016). However, the role and behaviour of the litter layer accumulation in long of successional process is not yet well known, with more studies being necessary.

\section{Relationship weather vs. litterfall and litter layer}

The months with low rainfall had the lowest litterfall rate, however at the end of the dry season (Sep. and Oct. of 2011) high litterfall rate was found even with low rainfall (Figure 1). Using the Kaiser-Guttman criteria the variation of the climatic data and the litterfall could be represented by two PCA axis. The first axis explained 53\% of the data variance, and the second $25 \%$. With this analysis, we could observe that the highest litterfall rate was found in the month with low air humidity, high radiation, temperature, and wind speed (Figure 2). 


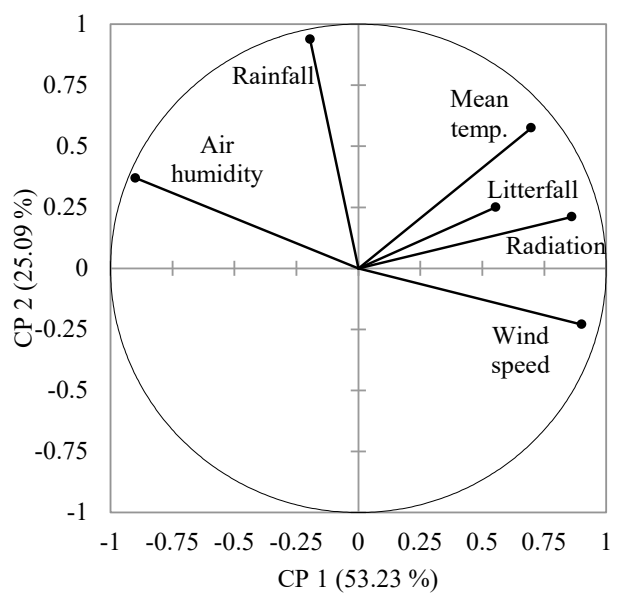

Figure 2. Principal Component Analysis of the weather data with the litterfall production of a semi deciduous Atlantic Forest.

The variance of the climatic data with the litter layer accumulated on the soil was explained by two axes. The first two axes explained $58 \%$ and the second $26 \%$ of the data variation respectively. With this analysis, it was possible to observe that the highest litter layer amount was found in the months with high wind speed, radiation, and temperature and the lowest in the month with high rainfall and air humidity (Figure 3).

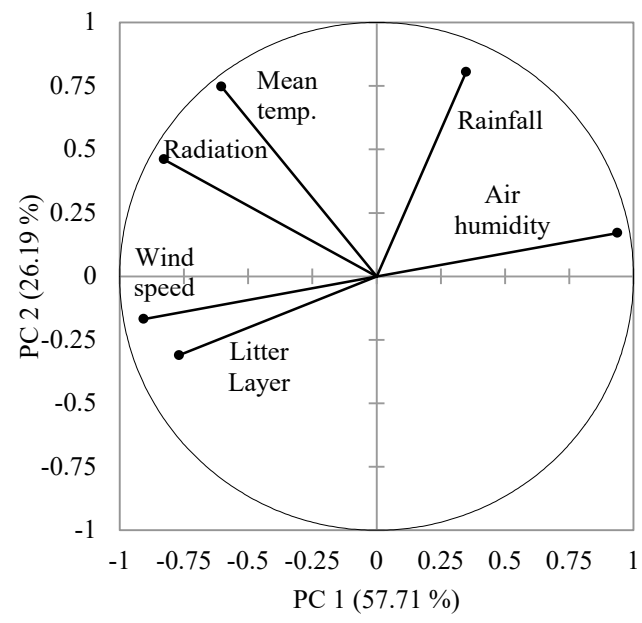

Figure 3. Principal Component Analysis of the weather data with the litter layer amount of a semi deciduous Atlantic Forest.

Some studies in different forest types show a weak relationship between weather conditions and litterfall and litter layer (Corrêa et al., 2013; Godinho et al., 2013a; Schumacher et al., 2013; Turchetto \& Fortes, 2014; Vogel et al., 2007). On the other hand, other studies, (such as this) have found a strong relationship between litter, air temperature, and precipitation (Santos \& Válio, 2002; Scoriza \& Piña-Rodrigues, 2014; Antoneli \& Francisquini, 2015). Wood et al. (2006) pointed out that, although the magnitude of nutrient fluxes may be controlled by local factors such as soil fertility, temporal patterns are likely regulated by a common environmental variable such as precipitation or temperature. These different behaviours in different types of forest can be associated with evolutionary processes which have determined the distribution of species well adapted to each environmental condition (Turchetto \& Fortes, 2014). 
Studies in some primary forests have shown that water stress reduces the green colour intensity of the leaves (Samanta et al., 2012; Xu et al., 2011), the leaf area index (Hilker et al., 2014) and the net primary production (Lewis et al., 2011). Brando et al. (2008) reported that the dry season between 1999 and 2005 in the Amazon forest resulted in reduction of wood production (reducing $13 \%$ in the first year and reaching $62 \%$ in the followed years) and reduction in the litterfall (in 23\%) after the third year. Following the drought, litterfall and growth rates recovered quickly.

\section{CONCLUSION}

The highest litterfall rate and litter layer accumulation was found in the end of the dry season, this being a normal behaviour for this forest typology. A trend of increased decomposition rate from the top to the bottom of the hill was found, but topography gradient did not affect the litterfall or litter layer. Despite the high seasonality, weather conditions were weakly correlated with litterfall and litter layer, however higher correlations were found with air temperature and humidity. Litterfall is an important mechanism for the transference of nutrients from plants to soil, especially the non-mobile nutrients and $\mathrm{N}$, due to a high dominance of the Fabaceae family trees. In 17 months, around $6.7 \mathrm{Mg} \mathrm{ha}^{-1}$ of $\mathrm{C}$ was deposited on the soil and a mean $2.6 \mathrm{Mg} \mathrm{ha}^{-1}$ were stored in the litter layer. In the year 2010, in the 12 months, the annual decomposition rate was 1.68 .

\section{ACKNOWLEDGMENTS}

The authors thank the owners of RPPN Cafundó.

\section{REFERENCES}

Alvares, C. A., Stape, J. L., Sentelhas, P. C., Gonçalves, J. L. M., \& Sparovek, G. (2013). Köppen's climate classification map for Brazil. Meteorologische Zeitschrift, 22(6), 711-728. http://dx.doi.org/10.1127/0941-2948/2013/0507.

Alves, L. F., Assis, M. A., Van Melis, J., Barros, A. L. S., Vieira, S. A., Martins, F. R., Martinelli, L. A., \& Joly, C. A. (2012). Variation in liana abundance and biomass along an elevational gradient in the tropical Atlantic Forest (Brazil). Ecological Research, 27(2), 323-332. http://dx.doi.org/10.1007/s11284-0110902-8.

Alves, L. F., Vieira, S. A., Scaranello, M. A., Camargo, P. B., Santos, F. A. M., Joly, C. A., \& Martinelli, L. A. (2010). Forest structure and live aboveground biomass variation along an elevational gradient of tropical Atlantic moist forest (Brazil). Forest Ecology and Management, 260(5), 679-691. http://dx.doi.org/10.1016/j.foreco.2010.05.023.

Anderson, J. M., Proctor, J., \& Vallack, H. W. (1983). Ecological studies in four contrasting lowland rain forests in Gunung Mulu National Park, Sarawak: III. Decomposition processes and nutrient losses from leaf litter. Journal of Ecology, 71(2), 503-527. http://dx.doi.org/10.2307/2259731.

Antoneli, V., \& Francisquini, V. (2015). Influência de alguns elementos climáticos na produção de serrapilheira em um reflorestamento de pinus na FLONA (Floresta Nacional) de Irati- PR. Caderno de Geografia, 25(44), 176-190. http://dx.doi.org/10.5752/P.2318-2962.2015v25n44p176.

Arato, H. D., Martins, S. V., \& Ferrari, S. H. D. S. (2003). Produção e decomposição de serapilheira em um sistema agroflorestal implantado para recuperação de área degradada em Viçosa-MG. Revista Árvore, 27(5), 715-721. http://dx.doi.org/10.1590/S0100-67622003000500014.

Archanjo, K. M. P. D. A., Silva, G. F., Chichorro, J. F., \& Soares, C. P. B. (2012). Estrutura do componente arbóreos da Reserva Particular do Patrimônio Natural Cafundó, Cachoeiro de Itapemirim, Espírito Santo, Brasil. Revista Floresta, 42(1), 145-160. http://dx.doi.org/10.5380/rf.v42i1.26311.

Aryal, D. R., De Jong, B. H. J., Ochoa-Gaona, S., Mendoza-Vega, J., \& Esparza-Olguin, L. (2015). Successional and seasonal variation in litterfall and associated nutrient transfer in semi-evergreen tropical forests of SE Mexico. Nutrient Cycling in Agroecosystems, 103(1), 45-60. http://dx.doi.org/10.1007/s10705-015-9719-0.

Attwill, P. M. (1995). Nutrient cycling in forests. In W. A. Nierenberg (Ed.), Encyclopedia of environmental biology (pp. 625-639). San Diego: Academic Press. 
Bachega, L. R., Bouillet, J.-P., Piccolo, M. C., Saint-André, L., Bouvet, J.-M., Nouvellon, Y., Gonçalves, J. L. M., Robin, A., \& Laclau, J.-P. (2016). Decomposition of Eucalyptus grandis and Acacia mangium leaves and fine roots in tropical conditions did not meet the Home Field Advantage hypothesis. Forest Ecology and Management, 359, 33-43. http://dx.doi.org/10.1016/j.foreco.2015.09.026.

Backes, A., Prates, F. L., \& Viola, M. G. (2005). Produção de serapilheira em Floresta Ombrófila Mista, em São Francisco de Paula, Rio Grande do Sul, Brasil. Acta Botanica Brasílica, 19(1), 155-160. http://dx.doi.org/10.1590/S0102-33062005000100015.

Baldock, J. A., \& Skjemstad, J. O. (2000). Role of the soil matrix and minerals in protecting natural organic materials against biological attack. Organic Geochemistry, 31(7-8), 697-710. http://dx.doi.org/10.1016/S0146-6380(00)00049-8.

Bonner, M. T. L., Schmidt, S., \& Shoo, L. P. (2013). A meta-analytical global comparison of aboveground biomass accumulation between tropical Secondary forests and monoculture plantations. Forest Ecology and Management, 291, 73-86. http://dx.doi.org/10.1016/j.foreco.2012.11.024.

Borém, R. A. T., \& Ramos, D. P. (2002). Variação estacional e topográfica de nutrientes na serapilheira de um fragmento de Mata Atlântica. Cerne, 8, 42-59.

Brady, N. C., \& Weil, R. R. (2013). Elementos da natureza e propriedades dos solos (3. ed.). Porto Alegre: Bookman.

Brando, P. M., Nepstad, D. C., Davidson, E. A., Trumbore, S. E., Ray, D., \& Camargo, P. (2008). Drought effects on litterfall, wood production and belowground carbon cycling in an Amazon forest: results of a throughfall reduction experiment. Philosophical Transactions of the Royal Society of London. Series B, Biological Sciences, 363(1498), 1839-1848. PMid:18267902. http://dx.doi.org/10.1098/rstb.2007.0031.

Bray, J. R., \& Gorham, E. (1964). Litter production in forests of the world. Advances in Ecological Research, 2, 101-157. http://dx.doi.org/10.1016/S0065-2504(08)60331-1.

Brienen, R. J. W., Phillips, O. L., Feldpausch, T. R., Gloor, E., Baker, T. R., Lloyd, J., Lopez-Gonzalez, G., Monteagudo-Mendoza, A., Malhi, Y., Lewis, S. L., Vásquez Martinez, R., Alexiades, M., Álvarez Dávila, E., Alvarez-Loayza, P., Andrade, A., Aragão, L. E., Araujo-Murakami, A., Arets, E. J., Arroyo, L., Aymard C, G. A., Bánki, O. S., Baraloto, C., Barroso, J., Bonal, D., Boot, R. G., Camargo, J. L., Castilho, C. V., Chama, V., Chao, K. J., Chave, J., Comiskey, J. A., Cornejo Valverde, F., Costa, L., Oliveira, E. A., Di Fiore, A., Erwin, T. L., Fauset, S., Forsthofer, M., Galbraith, D. R., Grahame, E. S., Groot, N., Hérault, B., Higuchi, N., Honorio Coronado, E. N., Keeling, H., Killeen, T. J., Laurance, W. F., Laurance, S., Licona, J., Magnussen, W. E., Marimon, B. S., Marimon-Junior, B. H., Mendoza, C., Neill, D. A., Nogueira, E. M., Núñez, P., Pallqui Camacho, N. C., Parada, A., Pardo-Molina, G., Peacock, J., Peña-Claros, M., Pickavance, G. C., Pitman, N. C., Poorter, L., Prieto, A., Quesada, C. A., Ramírez, F., Ramírez-Angulo, H., Restrepo, Z., Roopsind, A., Rudas, A., Salomão, R. P., Schwarz, M., Silva, N., Silva-Espejo, J. E., Silveira, M., Stropp, J., Talbot, J., ter Steege, H., Teran-Aguilar, J., Terborgh, J., Thomas-Caesar, R., Toledo, M., Torello-Raventos, M., Umetsu, R. K., Van der Heijden, G. M., Van der Hout, P., Guimarães Vieira, I. C., Vieira, S. A., Vilanova, E., Vos, V. A., \& Zagt, R. J. (2015). Long-term decline of the Amazon carbon sink. Nature, 519(7543), 344-348. PMid:25788097. http://dx.doi.org/10.1038/nature14283.

Caldeira, M. V. W., Vitorino, M. D., Schaadt, S. S., Moraes, E., \& Balbinot, R. (2008). Quantificação de serapilheira e de nutrientes em uma Floresta Ombrófila Densa. Semina: Ciências Agrárias, 29(1), 5368. http://dx.doi.org/10.5433/1679-0359.2008v29n1p53.

Calvi, G. P., Pereira, M. G., \& Espídula Júnior, A. (2009). Produção de serapilheira e aporte de nutrientes em áreas de Floresta Atlântica em Santa Maria de Jetibá, ES. Ciência Florestal, 19(2), 131-138. http://dx.doi.org/10.5902/19805098404.

Chazdon, R. L., Broadbent, E. N., Rozendaal, D. M. A., Bongers, F., Zambrano, A. M. A., Aide, T. M., Balvanera, P., Becknell, J. M., Boukili, V., Brancalion, P. H., Craven, D., Almeida-Cortez, J. S., Cabral, G. A., de Jong, B., Denslow, J. S., Dent, D. H., DeWalt, S. J., Dupuy, J. M., Durán, S. M., Espírito-Santo, M. M., Fandino, M. C., César, R. G., Hall, J. S., Hernández-Stefanoni, J. L., Jakovac, C. C., Junqueira, A. B., Kennard, D., Letcher, S. G., Lohbeck, M., Martínez-Ramos, M., Massoca, P., Meave, J. A., Mesquita, R., Mora, F., Muñoz, R., Muscarella, R., Nunes, Y. R., Ochoa-Gaona, S., Orihuela-Belmonte, E., PeñaClaros, M., Pérez-García, E. A., Piotto, D., Powers, J. S., Rodríguez-Velazquez, J., Romero-Pérez, I. E., Ruíz, J., Saldarriaga, J. G., Sanchez-Azofeifa, A., Schwartz, N. B., Steininger, M. K., Swenson, N. G., Uriarte, M., Van Breugel, M., Van der Wal, H., Veloso, M. D., Vester, H., Vieira, I. C., Bentos, T. V., Williamson, G. B., \& Poorter, L. (2016). Carbon sequestration potential of second-growth forest regeneration in the Latin American tropics. Science Advances, 2(5), 1-10. PMid:27386528. http://dx.doi.org/10.1126/sciadv.1501639.

Cliff, N. (1988). The eigenvalues-greater-than-one rule and the reliability of components. Psychological Bulletin, 103(2), 276-279. http://dx.doi.org/10.1037/0033-2909.103.2.276. 
Corrêa, R. S., Schumacher, M. V., \& Momolli, D. R. (2013). Deposição de serapilheira e macronutrientes em povoamento de Eucalyptus dunnii Maiden sobre pastagem natural degradada no Bioma Pampa. Scientia Forestalis, 41, 65-74.

Cuevas, E., \& Medina, E. (1986). Nutrient dynamics within amazonian forest ecosystems. Oecologia, 68(3), 466-472. PMid:28311796. http://dx.doi.org/10.1007/BF01036756.

Cunha Neto, F. V., Leles, P. S. S., Pereira, M. G., Bellumath, V. G. H., \& Alonso, J. M. (2013). Acúmulo e decomposição da serapilheira em quatro formações florestais. Ciência Florestal, 23(3), 379-387. http://dx.doi.org/10.5902/1980509810549.

Cunha, G. C., Grendene, L. A., Durlo, M. A., \& Bressan, D. A. (1993). Dinâmica nutricional em Floresta Estacional Decidual com ênfase aos minerais provenientes da deposição da serapilheira. Ciência Florestal, 3(1), 35-64. http://dx.doi.org/10.5902/19805098284.

Cunha, G. D. M., Gama-Rodrigues, A. C., Gama-Rodrigues, E. F., \& Velloso, A. C. X. (2009). Biomassa e estoque de carbono e nutrientes em florestas montanas da mata atlântica na região norte do estado do Rio de Janeiro. Revista Brasileira de Ciência do Solo, 33(5), 1175-1185. http://dx.doi.org/10.1590/S0100-06832009000500011.

Dechen, A. R., \& Nachtigall, G. R. (2006). Micronutrientes. In M. S. Fernandes (Ed.), Nutrição mineral de plantas (pp. 327-354). Viçosa: Sociedade Brasileira de Ciência do Solo.

Delitti, W. B. C. (1995). Estudos de ciclagem de nutrientes: instrumentos para a análise funcional de ecossistemas terrestres. Oecologia Brasiliensis, 1(01), 469-486. http://dx.doi.org/10.4257/oeco.1995.0101.24.

Den Besten, J. W., Arts, B., \& Verkooijen, P. (2014). The evolution of REDD+: an analysis of discursiveinstitutional dynamics. Environmental Science \& Policy, 35, 40-48. http://dx.doi.org/10.1016/j.envsci.2013.03.009.

Diniz, A. R., Machado, D. L., Pereira, M. G., Balieiro, F. C., \& Menezes, C. E. G. (2015). Biomassa, estoques de carbono e de nutrientes em estádios sucessionais da Floresta Atlântica, RJ. Brazilian Journal of Agricultural Sciences, 10(3), 443-451. http://dx.doi.org/10.5039/agraria.v10i3a4264.

Diniz, S., \& Pagano, S. N. (1997). Dinâmica de folhedo em floresta mesófila semidecídua no município de Araras, SP. I - Produção, decomposição e acúmulo. Revista do Instituto Florestal, 9, 27-36.

Ferreira, L. S., Cattânio, J. H., \& Jardim, M. A. G. (2015). Efeito da topografia e da precipitação na florística e na produção de liteira em Caxiuanã, Pará. Revista Árvore, 39(6), 995-1005. http://dx.doi.org/10.1590/0100-67622015000600002.

Food and Agriculture Organization of the United Nations - FAO. (2015). World reference base for soil resources 2014: international soil classification system for naming soils and creating legends for soil maps (World Soil Resources Reports, No. 106). Rome: FAO.

Gilroy, J. J., Woodcock, P., Edwards, F. A., Wheeler, C., Baptiste, B. L. G., Medina Uribe, C. A., Haugaasen, T., \& Edwards, D. P. (2014). Cheap carbon and biodiversity co-benefits from forest regeneration in a hotspot of endemism. Nature Climate Change, 4(6), 503-507. http://dx.doi.org/10.1038/nclimate2200.

Godinho, T. O., Caldeira, M. V. W., Caliman, J. P., Prezotti, L. C., Watzlawick, L. F., Azevedo, H. C. A., \& Rocha, J. H. T. (2013a). Biomassa, macronutrientes e carbono orgânico na serapilheira depositada em trecho de floresta Estacional Semidecidual Submontana, ES. Scientia Forestalis, 41, 131-144.

Godinho, T. O., Caldeira, M. V. W., Rocha, J. H. T., Caliman, J. P., \& Vieira, M. (2013b). Fertilidade do solo e nutrientes na serapilheira em fragmento de Floresta Estacional Semidecidual. Ecologia e Nutrição Florestal, 1(3), 97-109. http://dx.doi.org/10.13086/2316-980x.v01n03a01.

Gonçalves, J. L. M., Alvares, C. A., Rocha, J. H. T., Brandani, C. B., \& Hakamada, R. (2017). Eucalypt plantation management in regions with water stress. Southern Forest: a Journal of Forest Science, 79(3), 169-183. http://dx.doi.org/10.2989/20702620.2016.1255415.

Guttman, L. (1954). Some necessary conditions for common-factor analysis. Psychometrika, 19(2), 149161. http://dx.doi.org/10.1007/BF02289162.

Heenan, D. P., \& Campbell, L. C. (1983). Manganese and iron interactions on their uptake and distribution in soybean (Glycine max (L.) Merr.). Plant and Soil, 70(3), 317-326. http://dx.doi.org/10.1007/BF02374888.

Hilker, T., Lyapustin, A. I., Tucker, C. J., Hall, F. G., Mynenid, R. B., Wang, Y., Bi, J., Moura, Y. M., \& Sellers, P. J. (2014). Vegetation dynamics and rainfall sensitivity of the Amazon. Proceedings of the National Academy of Sciences of the United States of America, 111(45), 16041-16046. PMid:25349419. http://dx.doi.org/10.1073/pnas.1404870111. 
Horwart, W. (2007). Carbon cycling and formation of soil organic matter. In E. A. Paul (Ed.), Soil microbiology, ecology and biochemistry (pp. 303-339). Amsterdam: Elsevier.

Instituto Brasileiro de Geografia e Estatística - IBGE. (2012). Manual técnico da vegetação brasileira (2. ed.). Rio de Janeiro: Instituto Brasileiro de Geografia e Estatística.

Jackson, D. A. (1993). Stopping rules in principal components analysis: a comparison of heuristical and statistical approaches. Ecology, 74(8), 2204-2214. http://dx.doi.org/10.2307/1939574.

Jenny, H., Gessel, S. P., \& Bingham, F. T. (1949). Comparative studies of the decomposition rates of organic matter in temperate and tropical regions. Soil Science, 68(6), 419-432. http://dx.doi.org/10.1097/00010694-194912000-00001.

Lewis, S. L., Brando, P. M., Phillips, O. L., Van Der Heijden, G. M. F., \& Nepstad, D. (2011). The 2010 Amazon drought. Science, 331(6017), 554-554. PMid:21292971. http://dx.doi.org/10.1126/science.1200807.

Lira, P. K., Ewers, R. M., Banks-Leite, C., Pardini, R., \& Metzger, J. P. (2012). Evaluating the legacy of landscape history: extinction debt and species credit in bird and small mammal assemblages in the Brazilian Atlantic Forest. Journal of Applied Ecology, 49(6), 1325-1333. http://dx.doi.org/10.1111/j.1365-2664.2012.02214.x.

Malavolta, E. (2006). Manual de nutrição mineral de plantas. São Paulo: Agronomica Ceres.

Marschner, H. (1995). Mineral nutrition of higher plants (2nd ed.). London: Academic Press.

Martinelli, L. A., Lins, S. R., \& Santos-Silva, J. C. (2017). Fine litterfall in the Brazilian Atlantic Forest. Biotropica, 49(4), 443-451. http://dx.doi.org/10.1111/btp.12448.

Martins, S. V., \& Rodrigues, R. R. (1999). Produção de serapilheira em clareiras de uma floresta estacional semidecidual no município de Campinas, SP. Revista Brasileira de Botânica. Brazilian Journal of Botany, 22(3), 405-412. http://dx.doi.org/10.1590/S0100-84041999000300009.

Menezes, C. E. G., Pereira, M. G., Correia, M. E. F., Anjos, L. H. C., Paula, R. R., \& Souza, M. E. (2010). Aporte e decomposição da serapilheira e produção de biomassa radicular em florestas com diferentes estágios sucessionais em Pinheiral, RJ. Ciência Florestal, 20(3), 439-452. http://dx.doi.org/10.5902/198050982059.

Moreira, P. R., \& Silva, A. O. (2004). Produção de serapilheira em área reflorestada. Revista Árvore, 28(1), 49-59. http://dx.doi.org/10.1590/S0100-67622004000100007.

Nilsson, L. O., Hüttl, R. F., Johansson, U. T., \& Jochheim, H. (1995). Nutrient uptake and cycling in forest ecosystems: present status and future research directions. In L. O. Nilsson, R. F. Hüttl \& U. T. Johansson (Eds.), Nutrient uptake and cycling in forest ecosystems (pp 5-13), Dordrecht: Springer Netherlands. http://dx.doi.org/10.1007/978-94-011-0455-5_1.

Olson, J. S. (1963). Energy storage and the balance of producers and decomposers in ecological systems. Ecology, 44(2), 322-331. http://dx.doi.org/10.2307/1932179.

Pan, Y., Birdsey, R. A., Fang, J., Houghton, R., Kauppi, P. E., Kurz, W. A., Phillips, O. L., Shvidenko, A., Lewis, S. L., Canadell, J. G., Ciais, P., Jackson, R. B., Pacala, S. W., McGuire, A. D., Piao, S., Rautiainen, A., Sitch, S., \& Hayes, D. (2011). A large and persistent carbon sink in the world's forests. Science, 333(6045), 988-993. PMid:21764754. http://dx.doi.org/10.1126/science.1201609.

Pandey, R. R., Sharma, G., Tripathi, S. K., \& Singh, A. K. (2007). Litterfall, litter decomposition and nutrient dynamics in a subtropical natural oak forest and managed plantation in northeastern India. Forest Ecology and Management, 240(1-3), 96-104. http://dx.doi.org/10.1016/j.foreco.2006.12.013.

Paudel, E., Dossa, G. G. O., Xu, J., \& Harrison, R. D. (2015). Litterfall and nutrient return along a disturbance gradient in a tropical montane forest. Forest Ecology and Management, 353, 97-106. http://dx.doi.org/10.1016/j.foreco.2015.05.028.

Peh, K. S.-H., Sonké, B., Taedoung, H., Séné, O., Lloyd, J., \& Lewis, S. L. (2012). Investigating diversity dependence of tropical forest litter decomposition: experiments and observations from Central Africa. Journal of Vegetation Science, 23(2), 223-235. http://dx.doi.org/10.1111/j.16541103.2011.01352.x.

Pereira, G. H. A., Pereira, M. G., Anjos, L. H. C., Amorim, T. A., \& Menezes, C. E. G. (2013). Decomposição da serapilheira, diversidade e funcionalidade de invertebrados do solo em um fragmento de Floresta Atlântica. Bioscience Journal, 29, 1317-1327.

Phillivs, O., Aragão, L., Lewis, S., Fisher, J., Lloyd, J., Lopez-Gonzalez, G., Malhi, Y., Monteagudo, A., Peacock, J., Quesada, C., Heijden, G., \& Almeida, S. (2009). Drought sensitivity of the Amazon carbon sink. IOP Conference Series: Earth and Environmental Science, 6(4), 042004. http://dx.doi.org/10.1088/1755-1307/6/4/042004. 
Pimenta, J. A., Rossi, L. B., Torezan, J. M. D., Cavalheiro, A. L., \& Bianchini, E. (2011). Produção de serrapilheira e ciclagem de nutrientes de um reflorestamento e de uma floresta estacional semidecidual no sul do Brasil. Acta Botanica Brasílica, 25(1), 53-57. http://dx.doi.org/10.1590/S010233062011000100008.

Pinto, S. I. D. C., Martins, S. V., Barros, N. F., \& Dias, H. C. T. (2008). Produção de serapilheira em dois estádios sucessionais de floresta estacional semidecidual na Reserva Mata do Paraíso, em Viçosa, MG. Revista Árvore, 32(3), 545-556. http://dx.doi.org/10.1590/S0100-67622008000300015.

Pires, L. A., Britez, R. M., Martel, G., \& Pagano, S. N. (2006). Produção, acúmulo e decomposição da serapilheira em uma restinga da Ilha do Mel, Paranaguá, PR, Brasil. Acta Botanica Brasílica, 20(1), 173-184. http://dx.doi.org/10.1590/S0102-33062006000100016.

Poorter, L., Bongers, F., Aide, T. M., Almeyda Zambrano, A. M., Balvanera, P., Becknell, J. M., Boukili, V., Brancalion, P. H., Broadbent, E. N., Chazdon, R. L., Craven, D., de Almeida-Cortez, J. S., Cabral, G. A., de Jong, B. H., Denslow, J. S., Dent, D. H., DeWalt, S. J., Dupuy, J. M., Durán, S. M., Espírito-Santo, M. M., Fandino, M. C., César, R. G., Hall, J. S., Hernandez-Stefanoni, J. L., Jakovac, C. C., Junqueira, A. B., Kennard, D., Letcher, S. G., Licona, J. C., Lohbeck, M., Marín-Spiotta, E., Martínez-Ramos, M., Massoca, P., Meave, J. A., Mesquita, R., Mora, F., Muñoz, R., Muscarella, R., Nunes, Y. R., OchoaGaona, S., de Oliveira, A. A., Orihuela-Belmonte, E., Peña-Claros, M., Pérez-García, E. A., Piotto, D., Powers, J. S., Rodríguez-Velázquez, J., Romero-Pérez, I. E., Ruíz, J., Saldarriaga, J. G., Sanchez-Azofeifa, A., Schwartz, N. B., Steininger, M. K., Swenson, N. G., Toledo, M., Uriarte, M., Van Breugel, M., Van der Wal, H., Veloso, M. D., Vester, H. F., Vicentini, A., Vieira, I. C., Bentos, T. V., Williamson, G. B., \& Rozendaal, D. M. (2016). Biomass resilience of Neotropical secondary forests. Nature, 530(7589), 211-214. PMid:26840632. http://dx.doi.org/10.1038/nature16512.

R Core Team. $R$ : a language and environment for statistical computing. Vienna: R Foundation for Statistical Computing. URL https://www.R-project.org/. 2017.

Rocha, J. H. T., Gonçalves, J. L. M., Godinho, T. O., \& Souza Filho, L. F. S. (2015). Nutrição e fertilização com enxofre e uso de gesso em plantações de eucalipto. Circular Técnica IPEF, 208, 1-14.

Samanta, A., Knyazikhin, Y., Xu, L., Dickinson, R. E., Fu, R., Costa, M. H., Saatchi, S. S., Nemani, R. R., \& Myneni, R. B. (2012). Seasonal changes in leaf area of Amazon forests from leaf flushing and abscission. Journal of Geophysical Research. Biogeosciences, 117, 1-13.

Santos, S. L., \& Válio, I. F. M. (2002). Litter accumulation and its effect on seedling recruitment in a Southeast Brazilian Tropical Forest. Revista Brasileira de Botânica, 25(1), 89-92. http://dx.doi.org/10.1590/S0100-84042002000100011.

Scheer, M. B. (2008). Decomposição e liberação de nutrientes da serapilheira foliar em um trecho de floresta ombrófila densa aluvial em regeneração, Guaraqueçaba (PR). Revista Floresta, 38(2), 253266. http://dx.doi.org/10.5380/rf.v38i2.11620.

Schumacher, M. V., Corrêa, R. S., Viera, M., \& Araújo, E. F. (2013). Produção e decomposição de serapilheira em um povoamento de Eucalyptus urophylla $\times$ Eucalyptus globulus maidenii. Cerne, 19(3), 501-508. http://dx.doi.org/10.1590/S0104-77602013000300018.

Schumacher, M. V., Trüby, P., Marafiga, J. M., Viera, M., \& Szymczak, D. A. (2011). Espécies predominantes na deposição de serapilheira em fragmento de floresta estacional decidual no Rio Grande do Sul. Ciência Florestal, 21(3), 475-482. http://dx.doi.org/10.5902/198050983805.

Scoriza, R. N., \& Piña-Rodrigues, F. C. M. (2014). Influência da precipitação e temperatura do ar na produção de serapilheira em trecho de floresta estacional em Sorocaba, SP. Revista Floresta, 44(4), 687-696. http://dx.doi.org/10.5380/rf.v44i4.34274.

Silva, F. B., Shimabukuro, Y. E., Aragão, L. E. O. C., Anderson, L. O., Pereira, G., Cardozo, F., \& Arai, E. (2013). Large-scale heterogeneity of Amazonian phenology revealed from 26-year long AVHRR/NDVI time-series. Environmental Research Letters, 8(2), 024011. http://dx.doi.org/10.1088/17489326/8/2/024011.

Silva, F. C. (2009). Manual de análises químicas de solos, plantas e fertilizantes (2. ed.). Brasília: Embrapa Informática Agropecuária.

Souza-Neto, E. R., Lins, S. R. M., Martins, S. C., Piccolo, M. C., Ferreira, M. L., Camargo, P. B., Carmo, J. B., Mazzi, E. A., Houlton, B. Z., \& Martinelli, L. A. (2017). Litterfall mass and nutrient fluxes over an altitudinal gradient in the coastal Atlantic Forest, Brazil. Journal of Tropical Ecology, 33(4), 261-269. http://dx.doi.org/10.1017/S0266467417000207.

Stevenson, F. J., \& Cole, M. A. (1999). Cycles of soils: carbon, nitrogen, phosphorus, sulfur, micronutrients (2nd ed.). New York: John Wiley \& Sons. 
Tedesco, M. J. (1995). Análises de solo, plantas e outros materiais (2. ed.). Porto Alegre: Departamento de Solos, UFRGS.

Turchetto, F., \& Fortes, F. O. (2014). Aporte e decomposição de serapilheira em Floresta Estacional Decidual na região do Alto Uruguai, RS. Pesquisa Florestal Brasileira, 34(80), 391-397. http://dx.doi.org/10.4336/2014.pfb.34.80.735.

Vital, A. R. T., Guerrini, I. A., Franken, W. K., \& Fonseca, R. C. B. (2004). Produção de serapilheira e ciclagem de nutrientes de uma floresta estacional semidecidual em zona ripária. Revista Árvore, 28(6), 793-800. http://dx.doi.org/10.1590/S0100-67622004000600004.

Vitousek, P. M., \& Sanford Junior, R. L. (1986). Nutrient cycling in moist tropical forest. Annual Review of Ecology and Systematics, 17(1), 137-167. http://dx.doi.org/10.1146/annurev.es.17.110186.001033.

Vogel, H. L. M., Schumacher, M. V., Trüby, P., \& Vuaden, E. (2007). Avaliação da devolução de serapilheira em uma floresta estacional decidual em Itaara, RS, Brasil. Ciência Florestal, 17(3), 187-196. http://dx.doi.org/10.5902/198050981950.

Wood, T. E., Lawrence, D., \& Clark, D. A. (2006). Determinants of leaf litter nutrient cycling in a tropical rain forest: soil fertility versus topography. Ecosystems, 9(5), 700-710. http://dx.doi.org/10.1007/s10021-005-0016-7.

Xu, L., Samanta, A., Costa, M. H., Ganguly, S., Nemani, R. R., \& Myneni, R. B. (2011). Widespread decline in greenness of Amazonian vegetation due to the 2010 drought. Geophysical Research Letters, 38(7), 1-4. http://dx.doi.org/10.1029/2011GL046824.

Zelarayán, M. L. C., Celentano, D., Oliveira, E. C., Triana, S. P., Sodré, D. N., Muchavisoy, K. H. M., \& Rousseau, G. X. (2015). Impacto da degradação sobre o estoque total de carbono de florestas ripárias na Amazônia Oriental, Brasil. Acta Amazonica, 45(3), 271-282. http://dx.doi.org/10.1590/1809-4392201500432.

Authors' contributions: JPC and TOG: conceptualization, data curation, formal analysis, investigation, methodology, validation, visualization, writing - original draft, writing - review \& editing; MVWC:

Conceptualization, funding acquisition, methodology, project administration, supervision, writing - original draft; JHTR: formal analysis, investigation, visualization, writing - original draft, writing - review \& editing; MLD and KCC: writing - original draft. 